\title{
HUBUNGAN ANTARA TINGKAT PENDIDIKAN IBU, WAKTU PERTAMA KALI PEMBERIAN MP-ASI, DAN STATUS EKONOMI DENGAN KEJADIAN GIZI KURANG PADA BALITA DI PUSKESMAS MAMBORO TAHUN 2018
}

\author{
Ella Anggi Famela S. Lalusu ${ }^{1}$, Andi Handriyati ${ }^{1 *}$, Ahmad Zaifullah ${ }^{1}$ \\ ${ }^{1}$ Program Studi Pendidikan Dokter, Fakultas Kedokteran Universitas Alkhairat, J1. Diponegoro No. 39 \\ Palu 94221, Sulawesi Tengah, Indonesia \\ *Corresponding author: Telp: +6282193635235 email: riapediatric@ gmail.com
}

\begin{abstract}
ABSTRAK
Upaya peningkatan status kesehatan dan gizi bayi/anak umur 0-24 bulan melalui perbaikan perilaku masyarakat dalam pemberian makanan merupakan bagian yang tidak dapat dipisahkan dari upaya perbaikan gizi secara menyeluruh. Ketidaktahuan tentang cara pemberian makanan bayi dan anak, dan adanya kebiasaan yang merugikan kesehatan, secara langsung dan tidak langsung menjadi penyebab utama terjadinya masalah kurang gizi pada anak, khususnya pada umur dibawah 2 tahun. Tujuan penelitian adalah untuk mengetahui hubungan tingkat pendidikan ibu, waktu pertama kali pemberian MPASI, dan status ekonomi dengan kejadian gizi kurang pada balita di Puskesmas Mamboro Tahun 2018. Penelitian ini merupakan penelitian analitik observasional dengan pendekatan Case Control, dimana case berjumlah 15 orang dan kontrol 15 orang. Hasil menunjukkan bahwa dengan uji Chi-square : Di wilayah kerja Puskesmas Mamboro didapatkan hubungan yang bermakna antara tingkat pendidikan ibu (p:0,000) saat pemberian MP-ASI (p:0,000) dan status ekonomi (p:0,000) dengan kejadian gizi kurang pada balita. Disimpulkan bahwa tingkat Pendidikan ibu, status ekonomi, serta saat pertama kali pemberian MP-ASI sangat berpengaruh terhadap kejadian gizi kurang pada balita.
\end{abstract}

Kata Kunci: MP-ASI, Balita, Tingkat Pendidikan, Status Ekonomi, Gizi Kurang

\begin{abstract}
Efforts to improve the health and nutritional status of infants / children aged 0-24 months through improvements in community behavior in feeding is an inseparable part of overall nutrition improvement efforts. Ignorance of how to feed infants and children, and the existence of habits that are detrimental to health, directly and indirectly are the main causes of malnutrition in children, especially at the age of 2 years. The purpose of this study was to determine the relationship of maternal education level, when the MP-ASI was first given, and economic status with the incidence of malnutrition in infants at Mamboro Health Center in 2018. This study was an observational analytic study with a Case Control approach, in which case there were 15 people and control of 15 people. The results show that with the Chi-square test: In the working area of Mamboro Health Center, a significant relationship was found between the level of mother's education (p: 0,000) when giving MP-ASI (p: 0,000) and economic status (p: 0,000) and the incidence of malnutrition in toddler. It was concluded that the mother's education level, economic status, as well as when giving the first MP-ASI greatly influenced the incidence of malnutrition in infants.
\end{abstract}

Keywords: MP-ASI, Toddler, Level of Education, Economic Status, Malnutrition

\section{PENDAHULUAN}

Pendidikan dikaitkan dengan segala sesuatu yang diketahui berkaitan dengan proses belajar. Jika pengetahuan tentang makanan pendamping ASI baik diharapkan prilaku terhadap makanan pendamping ASI juga baik.
Jika Tingkat pendidikan ibu kurang maka mempengaruhi status pula pada akhirnya gizi balita.Makin tinggi pengetahuan ibu balita,semakin tinggi akan kesadaran perannya dalam keluarga.(Jurnal kesehatan andalans 2015) 
Upaya peningkatan status kesehatan dan gizi bayi/anak umur 0-24 bulan melalui perbaikan perilaku masyarakat dalam pemberian makanan merupakan bagian yang tidak dapat dipisahkan dari upaya perbaikan gizi secara menyeluruh. Ketidaktahuan tentang cara pemberian makanan bayi dan anak, dan adanya kebiasaan yang merugikan kesehatan, secara langsung dan tidak langsung menjadi penyebab utama terjadinya masalah kurang gizi pada anak, khususnya pada umur dibawah 2 tahun bertambah umur bayi bertambah pula kebutuhan gizinya. Ketika bayi memasuki usia 6 bulan ke atas, beberapa elemen nutrisi seperti karbohidrat, protein dan beberapa vitamin dan mineral yang terkandung dalam ASI atau susu formula tidak lagi mencukupi. Sebab itu sejak usia 6 bulan, kepada bayi selain ASI mulai diberi makanan pendamping ASI (MP-ASI) Agar kebutuhan gizi bayi/anak terpenuhi.Dalam pemberian MP-Asi perlu diperhatikan waktu pemberian MP-ASI ,frekuensi porsi, pemilihan bahan makanan, cara pembuatan dan cara pemberiannya. Disamping itu perlu pula diperhatikan pemberian makanan pada waktu anak sakit dan bila ibu bekerja di luar rumah.Pemberian MP-ASI yang tepat diharapkan tidak hanya dapat memenuhi kebutuhan gizi bayi, namun juga merangsang keterampilon makan dan merangsang rasa percaya diri.

Beberapa permasalahan pemberian makanan pendamping ASI (MP-ASI) antara lain ; pemberian makanan pralaktat sebelum ASI keluar, kolostrum dibuang, pemberian MPASI terlalu dini atau terlambat, MP-ASI yang diberikan tidak cukup, pemberian MP-ASI sebelum Asi, frekuensi pemberian MP-ASI kurang, pemberian Asi terhenti karena ibu kembali bekerja, kebersihan kurang, prioritas gizi yang salah pada keluarga.

Bahaya dari pemberian MP ASI terlalu dini adalah Pemberian MP-ASI dini sama saja dengan membuka pintu gerbang masuknya berbagai jenis kuman sebab, system imun bayi dibawah 6 bulan masih belum sempurna.
Belum lagi jika tidak disajikan higienis. Hasil riset terakhir dari peneliti di Indonesia menunjukkan bahwa bayi yg mendapatkan MP-ASI sebelum ia berumur 6 bulan, lebih banyak terserang diare, sembelit, batuk-pilek, dan panas dibandingkan bayi yg hanya mendapatkan ASI eksklusif. Belum lagi penelitian dari badan kesehatan dunia lainnya.(Kementrian Kesehatan RI 2015)

Salah satu faktor yang mempengaruhi pemberian MP-ASI dini adalah status pekerjaan ibu. Ibu yang bekerja diluar rumah pada umumnya cenderung memberikan makanan pendamping Asi pada bayinya lebih cepat dari waktu yang ditetapkan, dikarenakan waktu yang dimiliki olehnya relatif singkat untuk berada bersama bayinya di dalam rumah. Konsumsi makanan berpengaruh terhadap status gizi seseorang. Status gizi yang baik atau optimal terjadi apabila tubuh memperoleh zat-zat gizi yang digunakan secara efisien, sehingga kemungkinan pertumbuhan fisik, perkembangan otak, kemampuan kerja dan kesehatan secara umum pada tingkat setinggi mungkin. Status gizi kurang terjadi bila tubuh mengalami kekurangan satu atau lebih zat-zat gizi esensisal. Status gizi lebih terjadi bila tubuh memperoleh zat-zat gizi dalam jumlah berlebihan sehingga menimbulkan efek toksis. Status gizi kurang atau lebih merupakan gangguan gizi.Turut sertanya ibu dalam mencari nafkah akan meningkatkan daya beli keluarga, akan tetapi juga menimbulkan masalah, yaitu pembagian waktu terutama dalam hal waktu untuk bekerja di luar rumah dengan waktu untuk mengelola rumah tangga serta mengasuh anak. Peran ganda ibu ini menuntut di satu pihak perlu curahan waktu penuh untuk mengasuh anak, bersamaan dengan itu perlu sisipan waktu untuk bekerja di luar rumah. Salah satu peluang untuk mengatasinya adalah anak diasuh oleh pembantu, keluarga atau family yang ada di rumah. Keterbatasan waktu ibu dalam mengasuh anak dan menyediakan makanan 
akan berpengaruh terhadap pola makan anak (bayi) dan konsumsi gizi anak, karena pada usia anak-anak ini merupakan usia yang membutuhkan konsumsi pangan yang ideal untuk membantu kecerdasan

Berdasarkan bukti efektivitas intervensi, pencapaian cakupan universal menyusui yang optimal dapat mencegah $13 \%$ angka kematian pada anak-anak kurang dari 5 tahun secara global, sementara praktek pemberian makanan pelengkap yang tepat mengurangi $6 \%$ angka mortalitas balita (WHO, 2009).

Pentingnya peningkatan gizi bagi generasi penerus bangsa menjadi perhatian serius Kementerian Kesehatan.Kewajiban kita semua untuk mempersiapkan anak sejak dini menjadi anak yang sehat, cerdas dan memiliki karakter sesuai dengan nilai-nilai bangsa Indonesia.

\section{METODOLOGI}

Penelitian ini dilakukan dengan menggunakan metode observasional analitik dengan pendekatan case control.Penelitian observasional analitik, yaitu jenis penelitian yang mencari hubungan antara variabel bebas dengan variabel terikat yang analisisnya untuk menentukan ada tidaknya hubungan antar variabel. Sedangkan pendekatan case control adalah mengamati secara retrospektif riwayat karakteristik atau paparan yang diduga mengakibatkan penyakit pada kelompok kasus kemudian dibandingkan dengan kelompok control.

\section{Populasi Penelitian}

1. Populasi penelitian : semua Balita yang ada di wilayah kerja Puskesmas Mamboro Palu

2. Populasi control : semua Balita yang ada di Wilayah kerja Puskesmas

Tabel 1 Pendidikan ibu berpengaruh terhadap status gizi
Mamboro yang tidak mengalami Gizi Kurang

\section{Subyek Penelitian}

1. Subyek penelitian : Subjek dalam penelitian ini balita yang terkena gizi kurang di wilayah kerja Puskesmas Mamboron Palu

2. Subyek control : Semua Balita di Wilayah kerja Puskesmas Mamboro Palu yang tidak menderita Gizi Kurang

\section{Cara Pengambilan Sampel}

Teknik pengambilan sample dalam penelitian ini adalah menggunakan desain case control dengan pendekatan non probability sampling :concecutive sampling yakni dengan mengambil semua data sampel balita yang menderita gizi kurang.

\section{Rencana Analisis Data}

Analisa data yang digunakan untuk mengetahui adanya hubungan tingkat pendidikan ibu, waktu pertama kali pemberian MP-ASI, dan Status ekonomi, dengan kejadian gizi kurang di Wilayah Kerja Puskesmas Mamboro Palu menggunakan analisa bivariat dengan metode chi square.

\section{HASIL DAN PEMBAHASAN}

HASIL

Penelitian ini dilakukan di Wilayah Kerja Puskesmas Mamboro pada bulan Juni-Agustus 2018 terhadap angka kejadian Gizi Kurang pada balita sejumlah 15 orang sebagai kelompok kasus dan 15 orang sebagai kelompok kontrol. Data diperoleh dari wawancara langsung kepada ibu penderita Gizi Kurang pada balita.

\begin{tabular}{|c|c|c|c|c|}
\hline & \multicolumn{2}{|c|}{ Gizi Kurang } & & \multirow[t]{2}{*}{$\mathrm{P}$} \\
\hline Pendidikan ibu & YA & TIDAK & TOTAL & \\
\hline SD & $\begin{array}{c}1 \\
100.0 \%\end{array}$ & $\begin{array}{c}0 \\
0.0 \%\end{array}$ & $\begin{array}{c}1 \\
100.0 \%\end{array}$ & \\
\hline
\end{tabular}




\begin{tabular}{ccccc} 
SMP & 4 & 0 & 4 & 0,000 \\
& $100.0 \%$ & $0.0 \%$ & $100.0 \%$ & \\
SMA & 10 & 15 & 25 & \\
& $40.0 \%$ & $60.0 \%$ & $100.0 \%$ & \\
\hline TOTAL & 15 & 15 & 30 & \\
& $50.0 \%$ & $50.0 \%$ & $100.0 \%$ \\
\hline
\end{tabular}

Keterangan: Nilai p dihitung berdasarkan uji chi-square. Nilai p bermakna

Hasil analisa tingkat pendidikan ibu menunjukkan ada hubungan yang bermakna $(\mathrm{p}<0,05)$. Dapat dilihat pada tabel 1.

Dari tabel diatas dapat disimpulkan bahwa ada hubungan yang bermakna antara tingkat pendidikan ibu dengan kejadian gizi kurang pada balita, walaupun OR tidak dapat

Tabel 2 Pemberian MP-ASI berpengaruh terhadap status gizi

\begin{tabular}{lcccc}
\hline Variable & \multicolumn{3}{c}{ Gizi Kurang } & \multirow{2}{*}{ P } \\
\cline { 2 - 4 } & YA & TIDAK & TOTAL & \\
\hline 2 bulan & 4 & 0 & 4 & \\
& $(100 \%)$ & $(0 \%)$ & $100.0 \%$ & \\
3 bulan & 8 & 0 & 8 & \\
& $(100 \%)$ & $(0 \%)$ & $100.0 \%$ & \multirow{2}{*}{ bulan } \\
5 bulan & 3 & 0 & 3 & \\
& $(100 \%)$ & $(0 \%)$ & $100.0 \%$ & \\
6 bulan & 0 & 6 & 6 & \\
& $(0 \%)$ & $(100 \%)$ & $100.0 \%$ & \\
\hline Total & 0 & 9 & 9 & \\
& $(0 \%)$ & $(100 \%)$ & $100.0 \%$ & \\
\hline
\end{tabular}

Keterangan: Nilai p dihitung berdasarkan uji chi-square. Nilai p bermakna

Hasil analisa pemberian MP-ASI pertamakali menunjukkan ada hubungan yang bermakna $(\mathrm{p}<0,05)$. Dapat dilihat pada tabel 2.

Dari tabel diatas dapat disimpulkan bahwa ada hubungan yang bermakna antara pemberian MP-ASI pertamakali dengan kejadian gizi kurang pada balita, walaupun OR tidak dapat dihitung. Dari 15 balita yang menderita gizi kurang (100\%).

Pada balita pemberian makanan pendamping-ASI usia 2 bulan dapat dapat dihitung. Dari 15 ibu yang mempunyai tingkat pendidikan rendah, jumlah balita gizi kurang (100\%) dan ibu yang mempunyai tingkat pendidikan baik semuanya tidak menderita gizi kurang kurang. 
Tabel 3 Status ekonomi berpengaruh terhadap status gizi

\begin{tabular}{lcccc}
\hline Variable & \multicolumn{2}{c}{ Gizi Kurang } & \multirow{2}{*}{$\mathrm{P}$} \\
\cline { 2 - 4 } & YA & TIDAK & TOTAL & \\
\hline Menengah & 3 & 15 & 18 & \\
& $(16,7 \%)$ & $(83,3 \%)$ & $100.0 \%$ & \\
Terendah & 12 & 0 & 12 & 0,000 \\
& $(100 \%)$ & $(0 \%)$ & $100.0 \%$ & \\
\hline Total & 15 & 15 & 30 & \\
& $(50 \%)$ & $(50 \%)$ & $100.0 \%$ & \\
\hline
\end{tabular}

Keterangan: Nilai p dihitung berdasarkan uji chi-square. Nilai p bermakna

Hasil analisa status ekonomi ibu menunjukkan ada hubungan yang bermakna $(\mathrm{p}<0,05)$. Dapat dilihat pada tabel 3.

Dari tabel diatas dapat disimpulkan bahwa ada hubungan yang bermakna antara status ekonomi ibu dengan kejadian gizi kurang pada balita, walaupun OR tidak dapat dihitung. Dari 15 ibu yang mempunyai tingkat ekonomi rendah, jumlah balita yang mengalami gizi kurang (100\%).

\section{PEMBAHASAN}

\section{Hubungan Tingkat Pendidikan ibu berpengaruh terhadap status gizi}

Dari hasil penelitian didapatkan hubungan yang bermakna antara tingkat pendidikan ibu dengan kejadian kejadian gizi kurang.Responden dengan tingkat pendidikan buruk lebih banyak dibandingkan tingkat pendidikan baik pada kelompok kasus. Hal ini sejalan dengan penelitian Sulistyowati Heny (2011) di kabupaten Blora bahwa pendidikan ibu Kabupaten Blora mengenai Gizi Kurang sebagian besar sudah baik yaitu sebesar 74,4\% (70 orang), sedangkan yang berpendidikan pengetahuan kurang sebesar 27,6\% (35 orang).Pendidikan ibu tentang Gizi Kurang pada balita yang baik akan membuat ibu memiliki kemampuan untuk merubah pengetahuannya.
Dari hasil analisis dengan uji Chi-Square didapatkan nilai $\mathrm{p}$ sebesar 0,000 yang berarti besar nilai $\mathrm{p}$ menyatakan terdapat hubungan antara pendidikan ibu dengan kejadian Gizi Kurang pada balita.

1. Waktu pertama pemberian MP-ASI berpengaruh terhadap status gizi

Dari hasil penelitian didapatkan hubungan yang bermakna antara waktu pertama kali pemberian MP-ASI.Responden dengan waktu pertama kali pemberian MP-ASI yang buruk lebih banyak mengalami Gizi Kurang dibanding waktu pertama kali pemberian MPASI yang baik pada kelompok kasus maupun kontrol.

\section{Status Ekonomi berpengaruh terhadap status gizi}

Dari hasil penelitian didapatkan hubungan yang bermakna anatar status ekonomi dengan kejadian kejadian gizi kurang.Responden dengan status ekonomi buruk lebih banyak dibandingkan status ekonomi baik pada kelompok kasus.

Dari hasil analisis dengan uji Chi-Square didapatkan nilai $\mathrm{p}$ sebesar 0,000 yang berarti besar nilai $\mathrm{p}$ menyatakan terdapat hubungan antara status ekonomi dengan kejadian Gizi Kurang pada balita. 


\section{KESIMPULAN}

Berdasarkan hasil penelitian dari pengambilan data di 15 sampel penderita yang ada di wilayah kerja Puskesmas Mamboro Palu tahun 2018, tentang Hubungan Tingkat Pendidikan Ibu, Waktu pertama Kali Pemberian MP-ASI, dan Status Ekonomi dengan Kejadian Gizi Kurang pada Balita Di Wilayah Kerja Puskesmas Mamboro Palu Tahun 2018, diperoleh kesimpulan sebagai berikut:

1. Ditemukan hubungan yang bermakna antara tingkat Pendidikan Ibu dengan Kejadian Gizi Kurang pada Balita di Wilayah Kerja Puskesmas Mamboro tahun 2018. Responden dengan tingkat Pendidikan buruk lebih banyak dibandingkan tingkat pendidikan baik pada kelompok kasus.

2. Ditemukan hubungan yang bermakna waktu pertama kali pemberian MP-ASI dengan kejadian Gizi Kurang pada Balita di Wilayah Kerja Puskemas mamboro tahun 2018. Responden dengan waktu pertama kali pemberian MP-ASI yang buruk lebih banyak dibanding dengan waktu pertama kali pemberian MP-ASI yang baik pada kelompok kasus.

3. Ditemukan hubungan yang bermakna antara status ekonomi dengan kejadian Gizi Kurang pada Balita di Wilayah Kerja Puskemas mamboro tahun 2018. Responden dengan status ekonomi yang rendah lebih banyak dibanding dengan status ekonomi yang tinggi pada kelompok kasus.

\section{DAFTAR PUSTAKA}

1. Infant and young child feeding Model Chapter for textbooks for medical students and allied health professionals: WHO; 2012.

2. PedomanPenggunaa KMS SK-Menkes: KEMENKES; 2010.

3. Succsess factors for women's and Chlidren's Health. Egypt: WHO Library Cataloguing-in-Publication Data; 2015. 